\title{
AN EMPERICAL STUDY OF THE IMPACT OF MARKETING MIX FACTOR ON TOURIST SATISFACTION: A CASE OF SELECTED THREE STATES IN INDIA
}

K. Lalromawia, School of Management Studies, University of Hyderabad

Prof. V Venkata Ramana, School of Management Studies, University of Hyderabad

dx.doi.org/10.18374//JBS-13-1.10

\begin{abstract}
Tourism industry is a fast growing industry and it becomes an increasingly important sector. The main purpose of this study is to examine the impact of marketing mix elements on tourists' satisfaction. The data for this study were collected verified structured questionnaire from sample of 300 tourists from domestic and international tourists. Target respondents were tourist who visited the three states in India namely Mizoram, Assam and Meghalaya. Data were analyzed with the help of software SPSS-17 version by adopting the statistical techniques, correlation and regression. The findings of the study showed that six out of seven marketing mix elements were positively related to tourists' satisfaction but price imposed by the authority is not satisfactory to the visitors'.
\end{abstract}

Keywords: 